\title{
FEATURES OF THE FORMATION OF THE DIGITAL ECONOMY
}

\author{
Khalikova Lola Nazarovna \\ Associate Professor, \\ Candidate of Economic Sciences, \\ of Samarkand Institute of Economics and Service
}

\begin{abstract}
Annotation. This article shows that an innovative and digital economy is one of the important factors in increasing the country's competitiveness and prosperity in the international arena. The economic development of Uzbekistan in the context of the globalization of the world economy and technological development is difficult to imagine without the rapid growth of the digital economy.

Key words: innovation, innovative economy, digital economy, digital technologies, information technologies, communications.
\end{abstract}

\section{Introduction}

Prominent Swedish economist and Nobel laureate Gunnar Myrdal provided an in-depth analysis of the developing country's economy in his 1968 book, The Asian Tragedy. He points out that the difficulties of economic growth in the least developed countries are not the lack of capital, as many Western experts say, but the lack of highly qualified specialists.

The development of economic relations, the growing role of modern information technology in the production of goods and services has led to the development of competition between countries and manufacturers around the world. The formation of an innovative and digital economy is becoming a priority in economically developed countries.

Many developed countries have adopted national strategic programs for the digital economy and society, such as the Digital Strategy 2025 in Germany and the Digital Agenda for Europe.

Innovation is an idea that has been put into practice and has commercial value, it can create new requirements, meet existing requirements more efficiently, and be economically, informationally, environmentally, socially, or otherwise effective in the optimal ratio of costs and results. For the development of the innovative economy, the Resolution of the President of the Republic of Uzbekistan Sh.M.Mirziyoyev dated November 29, 2017 "On the establishment of the Ministry of Innovative Development of the Republic of Uzbekistan" was adopted, and on December 13, 2018, on "Additional Measures for the Introduction of e-Government and Information Systems".

\section{The main part.}

Innovative and digital economy is becoming a key factor in the country's development, competitiveness and wellbeing. Of course, natural resources, geographical location, natural climatic conditions and other factors also prevail in the competitiveness of the world market. In an innovative and digital economy, the first country to implement scientific knowledge-based innovation and information telecommunications innovations will improve its position in the global market in terms of competitiveness. In the Republic of Uzbekistan, a number of measures are being taken by the state to develop an innovative and digital economy.

The problems of forming an innovative and digital economy in Uzbekistan are as follows.

The formation of a digital economy and e-government is one of the main indicators of the country's development. But to manage any highly advanced technology, you need professionals who can take full advantage of it.

In order to solve the problem of personnel in our country, the training of specialists in the field of innovation and digital economy is being organized. Innovative and digital economy sciences are being introduced as textbooks in universities, textbooks are being published. At the same time, we need to establish cooperation with leading experts and scientific and technical organizations abroad. We need to teach employees in all areas to use foreign languages and information and communication technologies effectively.

However, this is not enough to build the knowledge and skills of all segments of the population in the innovative and digital economy, for which it is important to organize short-term courses in the form of business trainings and online classes. Especially the employed population, inseparable from manufacturing would have access to knowledge.

Another important issue is that in order to take full advantage of the services of the digital economy and egovernment, all segments of the population, tourists, legal entities, individuals and all members of society in general should use quality and affordable Internet, mobile Internet services. The use of mobile internet, especially in mountainous, desert and remote areas of the country, opens the door to many opportunities. The speed of Internet communication is important in the search, transmission and reception of information. . This is especially important during online trading or stock trading, video conferencing and online communication. Because in modern society, whoever implements the first innovations, modernizes information and communication technologies and production techniques, has the advantage.

\section{Conclusion}

Innovative and digital economy, modern information technologies open many opportunities to increase the competitiveness of our country in the world market and ensure the well-being of the population, especially the effective 
use of communication services can solve many problems. First of all, there will be a need for highly qualified specialists who will be able to fully manage the highly developed technologies. Increasing the share of innovation and the digital economy in national income will increase the competitiveness of our country in international rankings, and most importantly, increase the living standards and welfare of our population.

In our opinion, in order to achieve positive results in the development of the digital economy in our country, it is expedient to carry out the following work:

- Creation of legal and regulatory framework for the formation of the infrastructure of the digital economy;

- Conducting conferences at the local level (higher education institutions, government agencies and private organizations) in order to raise awareness of the population about innovation and digital technologies;

- Use of experience of advanced foreign countries in the formation of the digital economy;

- Introduction of digital technologies in all industries and sectors and control over their activities;

- It is necessary to expand the types of online sales and their scale (such as Alibaba, Ebay, Amazon, which are convenient not only in Uzbekistan, but all over the world) We have already considered some aspects of this.

\section{List of used literature.}

1. Resolution of the President of the Republic of Uzbekistan Sh.M.Mirziyoyev "On measures to develop the digital economy in the Republic of Uzbekistan" PP - 3832 No 03.07.2018.

2. Resolution of the President of the Republic of Uzbekistan Sh.M.Mirziyoyev "On measures to further modernize the digital infrastructure for the development of the digital economy" No. PP-4022 of 21.11.2018.

3. Resolution of the President of the Republic of Uzbekistan Sh.M.Mirziyoyev dated November 29, 2017 No PF5264 "On the establishment of the Ministry of Innovative Development of the Republic of Uzbekistan".

4. Decree of the President of the Republic of Uzbekistan Sh.M.Mirziyoyev "On additional measures for the introduction of digital economy, e-government and information systems in public administration of the Republic of Uzbekistan."

5. Higher School of Economics - National Research University

Report, with the participation of the World Bank - Moscow - April 9-12, 2019.

Internet sites

8.https: //Kun.uz

9.https: //lex.uz 